\title{
EVALUATION OF A GENERAL ECOSYSTEM STATE INDICATOR BASED ON FARMLAND BIRDS
}

\author{
NAGY, G.G. ${ }^{1}$ - KOLLÁNYI, L. ${ }^{1}$ - FILEPNÉ KOVÁCS, K. ${ }^{1}$ - CZÚCZ, B. ${ }^{2}$ \\ ${ }^{I}$ Corvinus University of Budapest, Department of Landscape Planning and Regional \\ Development \\ H-1118 Budapest, Villányi út 29-43. \\ (phone: +36-1-482-6281; fax: +36-1-482-6338) \\ ${ }^{2}$ Hungarian Academy of Sciences, Centre for Ecological Research, Institute of Ecology and \\ Botany \\ *Corresponding author \\ e-mail: gergogabor.nagy@uni-corvinus.hu \\ (Received $23^{\text {rd }}$ July 2014; accepted $8^{\text {th }}$ Aug 2014)
}

\begin{abstract}
The comparison analysis and assessment of certain landscapes and landscape units is an effective tool for the decision makers for meeting appropriate land use decision. In our analysis we compared various groups of indices applicable for ecological landscape assessment applying them on three lowland landscape units. The assessed indices characterize the landscape from the point of view of vegetation (vegetation-based natural capital index) and birds (diversity of birds species of agricultural areas). The vegetation-based natural capital index values have been derived from the MÉTA database collected between 2003 and 2008. The ornithological survey was carried out in the spring of 2011 by modified Danish point counting system. Our sample areas were the geographical micro-regions Csepelisík, Hortobágy and Nagyberek, which are landscapes dominated by agricultural lands and grasslands. The major question was whether different naturalness indicators characterize basically similar but differently used landscape areas in a similar way. We found that while a higher NCI value corresponds to a higher abundance of birds, it also corresponds to a lower diversity of bird species. This contraintuitive effect partially might be explained by the variance of the large-scale landscape structure of the assessed landscape areas.
\end{abstract}

Keywords: biodiversity index, bird indices, habitat quality, vegetation-based natural capital index, naturalness

\section{Introduction}

One of the most serious environmental problems of our time is the loss of biodiversity caused by human activities which is associated by the continuous deterioration of the state of health of ecosystems (MEA, 2005; Rockström et al., 2009). The greatest difficulties in monitoring of biodiversity are the immense complexity of ecosystems, lack of financial resources, time, and lack of experts and appropriate technical conditions (Gregory and van Strien, 2010; Rodrigues and Brooks, 2007). To overcome these difficulties, various types of indicators are used to substitute for several parameters (Eglington et al., 2012; Gregory et al., 2005). These indicators aim at characterizing not only the compositional part of biodiversity, but the state of ecosystems in an integrated way (Noss, 1990; Niemeijer and de Groot, 2008). In addition to appropriately reflecting the condition of an ecosystem, such biodiversity indicators should also respond quickly to changes in the environment, and be easily monitored with sufficient information available about them (Dale and Beyeler, 2001). The most important goal of the development of such indicators is to measure the state

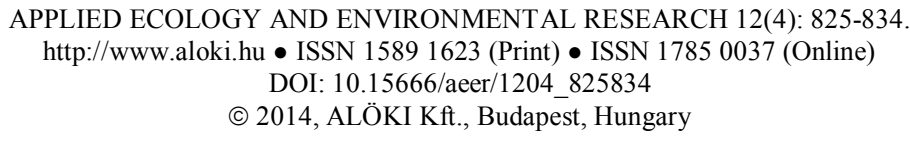


and trends of ecosystems and the ecological processes occurring in them (EEA, 2007; UNEP; 1992; van Strien et al., 2009). For the evaluation of the ecoystems and biodiversity states, as well as for monitoring of trends, different proxies are used, such as plants (Croft and Chow-Fraser, 2007) and birds (Bradford et al., 1998; Canterbury et al., 2000).

Currently, one of the key sectors in land use is agriculture. This kind of human activity is the most responsible for the disappearance and transformation of natural areas. In the beginning, traditional extensive farming did not result in diminishing diversity, however, by the second half of the $20^{\text {th }}$ century the significant population growth has had an increasing negative effect on the ecosystems with the use of machinery and various chemicals (crop protection products, fertilizers, etc.) (Reidsma et al., 2006). Diversity of agricultural landscapes was significantly reduced by the intensification of agriculture, starting from the $1600 \mathrm{~s}$ in the wake of the industrial revolution and further accelerated during the $19^{\text {th }}$ century (Donald et al., 2001). In case of several groups of organisms continuous population decrease were detected, particularly at birds. Since 1970 the population of farmland birds has decreased drastically, in many cases by $50 \%$ but the Grey Partrodge (Perdix perdix), Eurasian Sparrow (Passer montanus) Corn Bunting (Emberiza calandra) decreased by more than $80 \%$ (Siriwardena et al., 1998). It is clearly associated with the intensification of agriculture, changes of land use and plowing of former grassland (Aebisher et al., 2000; Gregory et al., 2005), which is especially in Western Europe and North America prominent (Herkert, 1994; Schifferli, 2000; Vickery et al., 2001), while in Central and Eastern Europe the negative effects are more nuanced (Verhulst et al., 2004). Agroenvironmental programmes were launched in the Member States of the European Union in order to reduce these harmful effects, promoting environmentally sound extensive farming methods (Ángyán, 2008).

In the light of these processes it is not at all surprising that most ecological indicators were developed for agrarian regions on a national and global scale (EEA, 2005; OECD, 1999). Most of the decision on the use of land is made locally, therefore the need to support decision making is most intense on the local and regional level. In order to adapt to this demand numerous international and regional indicators have been elaborated in recent years (Csorba, 2006; Dumortier et al., 2006), each of these indicators have a 'special approach' to landscape.

One of the most often used multi-species bird indicators was elaborated in the United Kingdom and Europe, which is the Farmland Bird Index, which describes the loss of biodiversity associated with agricultural intensification. The Farmland Bird Index (FBI) was set up in the United Kingdom to collectively monitor the 19 species of birds related primarily to agricultural areas (Gregory et al., 2005). The survey of abundance of bird species related to this index is based on the monitoring of the biodiversity of the easily observable and identified species (the birds) which reflects the ecologic state of the landscape. FBI is recognized as an official biodiversity indicator by the Central Statistical Office in Great-Britain and, in a modified form, also by EUROSTAT, the statistical office of the EU (Gregory et al., 2005).

Another promising indicator, which observes the landscape even in a more local way, is the vegetation-based natural capital index, elaborated in Hungary (Czúcz et al.; 2008). This indicator provides a flexible evaluation and comparable measurements for the general characterization of the natural status, based on plant (vegetation) data (Czúcz et al.; 2012). The concept of the Hungarian vegetation-based natural capital 
index is based on an indicator of similar name (Natural Capital Index, NCI) developed in the Netherlands at the end of the 1990s (ten Brink, 2000). The original formula expresses the differences between former and actual natural conditions of a complex landscape using numerical data:

$$
\mathrm{NCI}=\text { ecosystem quality } \times \text { ecosystem quantity }
$$

In the current study two different sets of biodiversity indicators (indicators based on bird data and indicators based on plant/vegetation data) with high potential in ecological landscape evaluation were compared on the example of three Hungarian lowland landscape units. Our main question was exploring the relation between the vegetation based natural capital and the main characteristics of the bird asemblages (abundance, species number, inverse Simpson-diversity, Shannon-diversity) observed at the same sites. We hypothesized that we will get the highest abundance and diversity of birds at sites with a relatively undisturbed close-to-natural state vegetation (high NCI value); and vice versa.

\section{Materials and methods}

In the year 2011 we selected three lowland geographical micro-regions with more or less of the same geographical characteristics based on the book entitled „Cadastre of landscape character units of Hungary" (Dövényi 2010): Csepeli-sík, Hortobágy and Nagyberek (Figure 1). Main characteristic of these micro-regions are high proportion of agricultural areas with agricultural plots covered by various vegetation cultures combined with dry and wet grassland. Csepeli-sík and Hortobágy are essentially characterized by large pannonic salt and pannonic loess steppes with marshlands wedged between them. Agricultural areas are typically divided into smaller lands with extensive cultivation. The northern and western parts of the Csepeli-sík are the exceptions, as they include large monocultures, a vast number of small lots as well and smaller and larger mine lakes. Because of the floodplains of the river Tisza and the related vegetation, the northern part of the Hortobágy is fundamentally different from the above described structure. Because of these characteristic differences of vegetation in case of lowland Csepeli-sík and Hortobágy we limited the survey for habitat mosaics and these were considered as landscape units. So we excluded from the survey the areas north to the road No. 51 and road Kiskunlacháza-Bugyi in case of lowland Csepeli-sík and areas north to the road No. 37 in Hortobágy. Similar to the above mentioned landscapes extensive agriculture dominates in Nagyberek, however we can find monocultural plots of greater scale as well. Previously water-covered habitats were featureless and the lower areas were covered by moorland and mud land. The vegetation of the three landscape units have their regional characteristics, but the composition of bird species settled over time is similar so they can be compared with each other. 


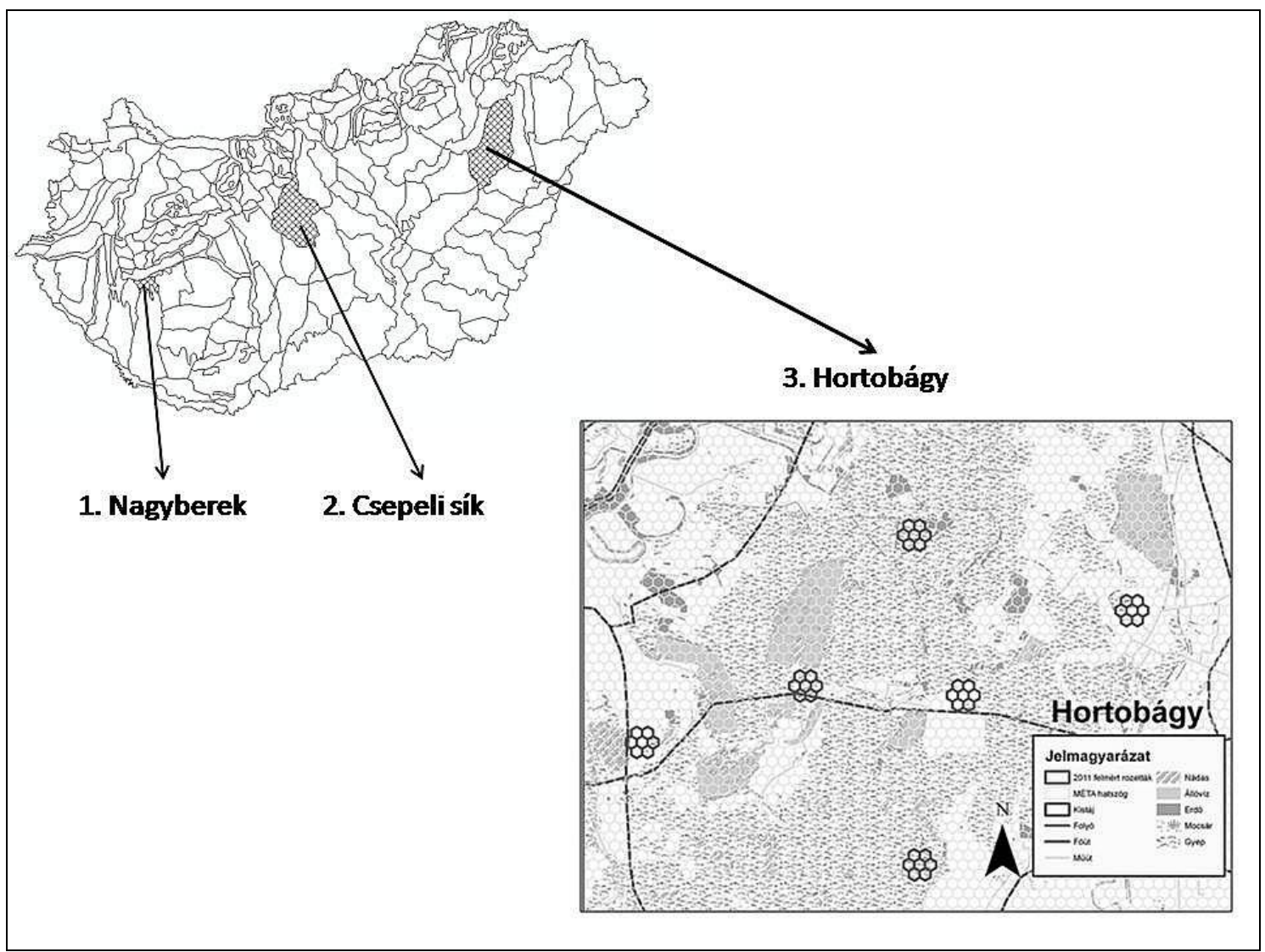

Figure 1. The location of the three plots in Hungary and the six selected rosette pattern in the Hortobágy

Six rosettes have been selected in each geographical micro-regions, each of which is part of one central and six surrounding MÉTA hexagons (these units of 7 hexagons can be approximated by a circle with a radius of $\sim 880 \mathrm{~m}$ and a ground area of 245 hectares) (Molnár et al., 2007). At the beginning of the designation process each landscape unit was divided into six parts, the center of each area was used as the point of origin for the search. We defined three designation criteria: the central point of the rosette could be accessed relatively easily; $80 \%$ of all the ground area of the seven MÉTA hexagons constituting the rosette could be accessible; there should be at least $70 \%$ open area within the rosette, cropland and/or grassland (based on the webpage www.pannongyep.hu and Google Earth). If the designation criteria were not met then heading east and moving along a spiral in clockwise direction we checked the subsequent potential center points until a suitable was found. In Nagyberek, the selection has been influenced mostly by closed private areas and conservation restrictions at the Csepeli-sík, as we were only allowed to enter areas for purposes of ornithological recording that were exempt from these restrictions. Our data are derived from seven hexagons in each of the six rosettes, i.e. 42 in each lowland landscape units and 126 hexagons in total (survey points). The determination of vegetation-based natural capital index based on the MÉTA mapping has been carried out between 2003 and 2008, Figure 2 shows the methodology (Czúcz et al., 2008; Czúcz et al., 2012). 


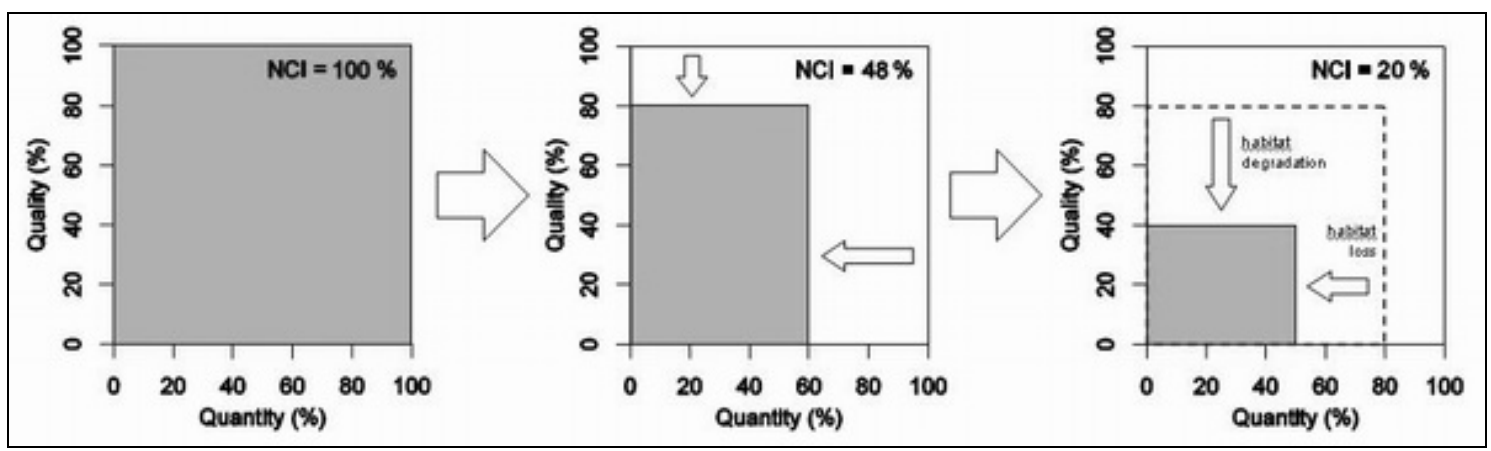

Figure 2. Demonstrating the calculation of NCI: the NCI value of an area equals the product of the quality and quantity of the remaining natural and semi-natural areas, which falls into the interval [0,1]. For example, if the half of the habitats is destroyed in an area and the naturalness of the remaining ones is reduced to $40 \%$, that means only the $20 \%$ of the original natural capital remains in the area (Czúcz et al., 2008; Czúcz et al., 2012).

The ornithological survey has been carried out between 20 April and 15 June 2011. All rosettes were surveyed in one occasion between 5 am to 10 am of the same day. We applied the modified Danish point counting method (Báldi et al., 1997). The center points of each hexagon served as survey points, around which the species heard and sighted within a circle of $100 \mathrm{~m}$ were registered. During the counting we also registered other species which were using the territory in other activities mostly for feeding and resting. For some species (e.g. great egret, Egretta alba) which startle and leave or avoid the survey area upon our approach, individuals observed within 5 minutes before and after the observation were also recorded and included in the sampling The data evaluation was focused on the population of bird species included into the EU Farmland Bird Index (FBI species). We analyzed the abundance values of the bird species according the Farmland Bird Index (Table 1, Gregory et al., 2005; http://www.rspb.org.uk/ourwork/farming/whyfarming/whyfarming/fbi/).

Table 1. Bird species belonging to the Farmland Bird Index (Gregory et al., 2005; http://www.rspb.org.uk/ourwork/farming/whyfarming/whyfarming/fbi/).

\begin{tabular}{|c|c|c|}
\hline No. & English name & Scientific name \\
\hline 1. & Grey Partridge & Perdix perdix \\
\hline 2. & Common Kestrel & Falco tinnunculus \\
\hline 3. & Northern Lapwing & Vanellus vanellus \\
\hline 4. & Rock Dove & Columba livia \\
\hline 5. & Common Wood Pigeon & Columba palumbus \\
\hline 6. & European Turtle Dove & Streptopelia turtur \\
\hline 7. & Eurasian Skylark & Alauda arvensis \\
\hline 8. & Western Yellow Wagtail & Motacilla flava \\
\hline 9. & Common Whitethroat & Sylvia communis \\
\hline 10. & Western Jackdaw & Corvus monedula \\
\hline 11. & Rook & Corvus frugilegus \\
\hline 12. & Common Starling & Sturnus vulgaris \\
\hline 13. & Eurasian Tree Sparrow & Passer montanus \\
\hline 14. & Yellowhammer & Emberiza citrinella \\
\hline 15. & Common Reed Bunting & Emberiza schoeniclus \\
\hline 16. & European Goldfinch & Carduelis carduelis \\
\hline 17. & European Greenfinch & Carduelis chloris \\
\hline 18. & Common Linnet & Carduelis cannabina \\
\hline 19. & Corn Bunting & Emberiza calandra \\
\hline
\end{tabular}


To characterize the diversity of bird associations the number of species, the total abundance, the inverse Simpson-index, and the Shannon-index were used; for comparing the similarity of the set of species the Jaccard-index was applied. To evaluate the similarity of perceptions provided by various indices on variant areas we used linear models with various bird-indices (number of species, inverse Simpson and Shannon indices and total abundance) as dependent variables, while the NCI value of each rosette was used as the independent variable and the three micro-regions were the categorical variables. As the diversity indices are not necessarily normally distributed square-root variance-stabilizing transformations were applied to the number of species and the inverse Simpson-index. The analysis was carried out with the $\mathrm{R}$ statistical software package (R Development Core Team 2011).

\section{Results}

The values of Natural Capital Index based on six-six sample areas are the following: Nagyberek 11\%, Csepeli-sík 30\% and Hortobágy 45\%. Number of FBI species is the following: the highest number of species has been found on Csepeli-sík, the second highest value has been at Nagyberek and the third has been on the Hortobágy. We excluded the flocking rook (Corvus frugilegus) from the records as we considered that to reliably capture the relatively rare occurrences of the large flocks of these birds would demand much higher survey efforts and different sampling approaches. Therefore we have found the highest bird density in Hortobágy and in Csepeli-sík. Nagyberek region counted significantly less bird population. With respect of the nearly identical values received for Hortobágy and Csepeli-sík it should be noted that the number of individual (269) in the former lowland area was distributed across 11 species, while in the latter case the 256 birds seen or heard accounted for 15 different species (Table 2).

Table 2. Some parameters of farmland bird species in the three lowland geographical microregions $(*$ the number of individual is equal the number of territories; ** except of Rook Corvus frugilegus).

\begin{tabular}{|c|c|c|c|}
\hline & Nagyberek & Csepeli-sík & Hortobágy \\
\hline Natural Capital Index & $11 \%$ & $30 \%$ & $45 \%$ \\
\hline Number of species & 14 & 16 & 12 \\
\hline Number of individuals* & $172^{* *}$ & $256^{* *}$ & $269^{* *}$ \\
\hline Shannon-diversity index & 2,2722 & 2,0432 & 1,4264 \\
\hline
\end{tabular}

The values of Jaccard-index used to analyse the similarity of species was $76 \%$ in comparison of Csepeli-sík and Nagyberek, $75 \%$ in comparison of Csepeli-sík and Hortobágy and 53\% in comparison of Nagyberek and Hortobágy. The survey of the five most frequent species refers clearly to a large degree of similarity between Csepeli-sík and Hortobágy (Table 3).

Table 3. The most frequent farmland bird species in the three lowland geographical microregions and their number of individual (the number of individual is equal the number of territories, except Rook Corvus frugilegus).

\begin{tabular}{|c|c|c|}
\hline Nagyberek & Csepeli-sík & Hortobágy \\
\hline Sturnus vulgaris (47) & Alauda arvensis (90) & Corvus frugilegus (280) \\
\hline
\end{tabular}




\begin{tabular}{|c|c|c|}
\hline Sylvia communis (31) & Corvus frugilegus (89) & Alauda arvensis $(130)$ \\
\hline Motacilla flava (26) & Vanellus vanellus $(46)$ & Motacilla flava (64) \\
\hline Corvus frugilegus $(15)$ & Emberiza calandra (32) & Emberiza calandra (32) \\
\hline Alauda arvensis (12) & Motacilla flava (29) & Sturnus vulgaris (15) \\
\hline
\end{tabular}

The linear models showed that the diversity of the bird species has significant correlation with the vegetation-based natural capital index (NCI) of the area. Nevertheless the direction of this correlation was surprising: the studied community diversity indices (inverse Simpson and Shannon-diversity) reflect a decline with the increase of NCI (Table 4). The correlation between the vegetation-based natural capital index and the number of species was not significant. The total abundance exhibits a marginally significant positive correlation with the NCI, reverse to the diversity indices: the greater the NCI of a rosette the greater the total number of observed birds is. The effect of landscape units (geographical micro-regions) and the interaction between the landscape unit and vegetation-based natural capital index was not significant in any case (Table 4).

Table 4. Interaction between vegetation-based natural capital index (NCI), lowland geographical micro-regions, number of species, inverz Simpson-index, Shannon-diversity index and total abundance ( $p$. = significance level, $p<0,05$ ).

\begin{tabular}{|c|c|c|c|c|}
\hline & NCI sign & p. NCI & $\begin{array}{c}\text { p. Lowland } \\
\text { geographical micro- } \\
\text { region }\end{array}$ & p. Interaction \\
\hline $\begin{array}{c}\text { Number of } \\
\text { species }\end{array}$ & -1 & 0,13489515 & 0,3960755 & 0,9219733 \\
\hline $\begin{array}{c}\text { Inverz Simpson- } \\
\text { index }\end{array}$ & -1 & $0,02068213^{*}$ & 0,3418034 & 0,778328 \\
\hline $\begin{array}{c}\text { Shannon- } \\
\text { diversity index }\end{array}$ & -1 & $0,02842609^{*}$ & 0,296472 & 0,861669 \\
\hline Total abundance & 1 & 0,07805489 & 0,1605993 & 0,146789 \\
\hline
\end{tabular}

\section{Discussion}

Verhulst et al. (2004) compared bird assemblages of extensively and intensively used grasslands and found that density and diversity were highest in abandoned areas. On the contrary, in our investigation the diversity indices were the lowest in the two most naturally reserved areas (Csepeli-sík and Hortobágy). We have to mention that in the study of Verhulst at al. (2004) a high number of species is not connected to the grassland areas. On the whole the naturalness of landscape parts are ordered differently by the vegetation-based natural capital index and the diversity indices of bird species since we observed a decrease in the inverse Simpson and Shannon-indices with the increase of NCI. The human landscape transformation and the large mosaicity of some of the landscape units might be the background of this phenomenon. Hortobágy, which is dominated by vast homogenous grassland areas, can support fewer FBI bird species, which are connected to agricultural areas, then Nagyberek, which is of a more complex mosaic structure. The prevalence of hedges and shelter belts made possible the settlement of forest bird species like common whitethroat (Sylvia communis) and common starling (Sturnus vulgaris) which contribute significantly to the increase of biodiversity values. The degree of human influence on the Csepeli-sík, sprinkled by 
alluvial forest fragments of the Danube valley, is between that of the two other sites, which is also indicated by its NCI values. Its set of species is highly identical to that of the Nagyberek, however the survey of the five most common bird species established a definite similarity with the Hortobágy.

The total set of results indicates that the examined ecological status indicators perceive and evaluate the landscapes differently, and there can be many differences of the details, meanwhile they are suitable for quick and superficial comparisons and for in-depth analysis as well. NCI, for example, is not suitable for handling local peak values and cannot express the large-scale naturalness of the landscape (Czúcz et al., 2012). This limitation can be partly eliminated by using bird indicators. Birds, as vagile species on the top of food chain are - with some limits -suitable to characterize the ecological status of the entire landscape at a larger scale than plants alone. Birds are highly sensitive to environmental changes, but the interpretation of changes is made difficult by many other factors e.g. the effects on migratory birds outside nesting time or factors influencing the quantity of prey animals (Gregory et al., 2005).

Bradford et al. (1998) compared areas grazed with various intensity using indicators characterizing bird communities, which provided results similar to ours: birds give a poor indication on the status of ecosystems. According to the results of Eglington et al. (2012) birds poorly indicate the wealth of other taxonomic groups in temperate grassland areas, on the other hand they give a much better indication on agricultural areas of more characteristic mosaic structure. Contrary to this, they function well as indicators in case of forest ecosystems (Canterbury et al., 2000). These statements direct the attention on the deviation of landscape assessment carried out with the help of plants and birds.

Acknowledgements. Research conducted by Gergő Gábor Nagy was completed with the generous support of the projects named 'TAMOP-4.2.1/B-09/1/KMR-2010-0005', 'TAMOP-4.2.2/B-10/1-20100023' and 'VITAL LANDSCAPES 2CE 164P3'. Bálint Czúcz was supported by the Bolyai grant of the Hungarian Academy of Sciences. We would like to thank Dóra Szabó who provided valuable comments to the study and Veronika Magyar for her help in fulfilling the formal requirement. Special thanks to Áron Kiss and Miklóst Lóránt for their assistance in ornithological surveys, and the authors would like to express their gratitude to the officials of the Kiskunság and Hortobágy National Parks for the entry permits issued to the protected areas of the Csepeli-sík and Hortobágy.

\section{REFERENCES}

[1] Aebisher, N. J., Evans, A. D., Grice, P. V. \& Vickery, J. A. (2000): Ecology and conservation of lowland farmland birds. - British Ornithologist's Union, Tring.

[2] Ángyán, J. (2008): Az agrárkörnyezet- és tájgazdálkodás hazai helyzete, kilátásai és a Nemzeti Vidékfejlesztési Terv. - In: Csorba, P. \& Fazekas, I. (szerk.): Tájkutatás Tájökológia. Meridián Alapítvány, Debrecen, pp. 19-30.

[3] Báldi, A., Moskát, Cs. \& Szép, T. (1997): Nemzeti Biodiverzitás-monitorozó Rendszer IX. Madarak. - Magyar Természettudományi Múzeum, Budapest.

[4] Bradford, D. F., Franson, S. E., Neale, A. C., Heggem, D. T., Miller, G. R. \& Canterbury, G. E. (1998): Bird species assemblages as indicators of biological integrity in Great Basin rangeland. Environ. - Environmental Monitoring and Assessment 49: 1-22.

[5] Canterbury, G. E., Martin, T. E., Petit, D. R., Petit, L. J. \& Bradford, D. F. (2000): Bird communities and habitat as ecological indicators of forest condition in regional monitoring. - Conservation Biology 14: 544-558. 
[6] Croft, M.V.\& Chow-Fraser, P. (2007): Use and development of the wetland macrophyte index to detect water quality impairment in fish habitat of Great Lakes coastal marshes. - Jornal of Great Lakes Resarch 33: 172-197.

[7] Czúcz, B., Molnár, Zs., Horváth, F. \& Botta-Dukát, Z. (2008): The natural capital index of Hungary. - Acta Botanica Hungarica 50(Suppl.): 161-177.

[8] Czúcz, B., Molnár, Zs., Horváth, F., Nagy, G. G., Botta-Dukát, Z. \& Török, K. (2012): Using the natural capital index framework as a scalable aggregation methodology for regional biodiversity indicators. - Journal for Nature Conservation 20: 144-152.

[9] Csorba, P. (2006): Indikátorok az ökológiai tájszerkezet és tájműködés vizsgálatához. - In: Kiss, A. Mezősi, G. \& Sümegi, Z. (szerk.): Táj, környezet és társadalom. Ünnepi tanulmányok Keveiné Bárány Ilona professzor asszony tiszteletére. Szeged.

[10] Dale, V. H. \& Beyeler, S. C. (2001): Challenges in the development and use of ecological indicators. - Ecological Indicators 1: 3-10.

[11] Donald, P. F., Green, R. E. \& Heath, M. F. (2001): Agricultural intensification and the colapse of Europe's farmland bird population. Proceedings of the Royal Society (London) Series B 268: 25-29.

[12] Dövényi, Z. (2010): Magyarország kistájainak katasztere. Második, átdolgozott és bővített kiadás. - MTA Földrajztudományi Kutatóintézet, Budapest.

[13] Dumortier, M., de Bruyn, L., Hens, M., Peymen, J., Schneiders, A., van Daele, T., van Reeth, W., Weyenbergh, G. \& Kuijken, E. (2006): Biodiversity Indicators 2006. State of Nature in Flanders (Belgium). - Research Institute for Nature and Forest, Brussels.

[14] EEA (European Environment Agency) (2005): Agriculture and environment in EU-15 the IRENA indicator report. - EEA, Copenhagen.

[15] EEA (European Environment Agency) (2007): Halting the loss of biodiversity by 2010: proposal for a first set of indicators to monitor progress in Europe. Technical report No. 11. - EEA, Copenhagen.

[16] Eglington, S. M., Noble, D. G. \& Fuller, R. J. (2012): A meta-analysis of spatial relationships in species richness across taxa: Birds as indicators of wider biodiversity in temperate regions. - Journal for Nature Conservation 20: 301-309.

[17] Gregory, R.D. \& van Strien, A. (2010): Wild bird indicators: using composite population trends of birds as measures of environmental health. - Ornithological Science 9: 3-22.

[18] Gregory, R. D., van Strien, A. J., Vorisek, P., Meyling, A. W. G., Noble, D. G., Foppen, R. P. B. \& Gibbons, D. W. (2005): Developing indicators for European birds. Philosophical Transactions for the Royal Society B 360: 269-288.

[19] Herkert, J. R. (1994): The effects of habitat fragmentation on midwestern grassland bird communities. Ecological Applications 4: 561-571.

[20] MEA (Millennium Ecosystem Assessment) (2005): Ecosystems and human well-being: Biodiversity synthesis. - World Resource Institue, Washington D.C.

[21] Molnár, Zs., Bartha, S., Seregélyes, T., Illyés, E., Botta-Dukát, Z., Tímár, G., Horváth, F., Révész, A., Kun, A., Bölöni, J., Biró, M., Bodonczi, L., Deák, J. Á., Fogarasi, P., Horváth, A., Isépy, I., Karas, L., Kecskés, F., Molnár, Cs., Ortmann-mé Ajkai, A. \& Rév, Sz. (2007): A grid-based, satellite-image supported, multi-attributed vegetation mapping method (MÉTA). - Folia Geobotanica 42: 225-247.

[22] Niemeijer, D. \& de Groot, R.S. (2008): A conceptual framework for selecting environmental indicator sets. - Ecological Indicators 8: 14-25.

[23] Noss, R.F. (1990): Indicators for monitoring biodiversity, a hierarchical approach. Conservation Biology 4: 355-364.

[24] OECD (Organisation for Economic Co-operation and Development) (1999): Environmental Indicators for Agriculture. Volume 3 Methods and Results. - OECD, Paris.

[25] Reidsma, P., Tekelenburg, T., van den Berg, M. \& Alkemade, R. (2006): Impacts of land use-change on biodiversity: An assessment of agricultural biodiversity in the European Union. - Agriculture, Ecosystems \& Environment 114: 86-102.

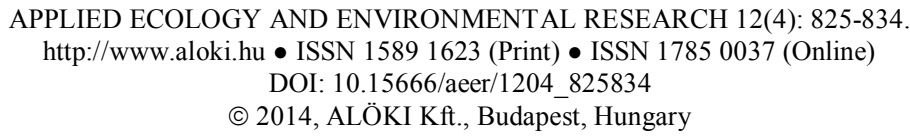


[26] Rockström, J., Steffen, W., Noone, K., Persson, Ĺ., Chapin, F. S., III, Lambin, E., Lenton, T. M., Scheffer, M., Folke, C., Schellnhuber, H., Nykvist, B., Wit, C. A. De, Hughes, T., van der Leeuw, S., Rodhe, H., Sörlin, S., Snyder, P. K., Costanza, R., Svedin, U., Falkenmark, M., Karlberg, L., Corell, R. W., Fabry, V. J., Hansen, J., Walker, B., Liverman, D., Richardson, K., Crutzen, P. \& Foley J. (2009): Planetary boundaries: exploring the safe operating space for humanity. - Ecology and Society 14(2): 32.

[27] Rodrigues, A. S. L. \& Brooks, T. M. (2007): Shortcuts for biodiversity conservation planning: The effectiveness of surrogates. - Annual Review of Ecology and Systematics 38: 713-737.

[28] R Development Core Team (2011): R: A language and environment for statistical computing. - R Foundation for Statistical Computing, Vienna, Austria. http://www.Rproject.org

[29] Schifferli, R. (2000): Changes of agriculture and the status of birds breeding in European farmland. - In: Aebisher, N. J., Evans, A. D., Grice, P. V. \& Vickery, J. A. (eds.): Ecology and conservation of lowland farmland birds. - British Ornithologists' Union, Tring.

[30] Siriwardena, G. M., Baillie, S. R., Buckland, S. T., Fewster, R. M., Marchant, J. H. \& Wilson, J. D. (1998): Trends in the abundance of farmland birds: a quantitative comparison os smoothed Common Birds Census indices. The Journal of Applied Ecology 35: 24-43.

[31] ten Brink, B. (2000): Biodiversity indicators for the OECD environmental outlook and strategy. A feasibility study. - RIVM report 402001014. Globio Report Series No 25. http://www.rivm.nl/ bibliotheek/rapporten/402001014.pdf.

[32] UNEP (United Nations Environment Programme) (1992): Convention on Biological Diversity. (biodiv.org/doc/legal/cbd-en.pdf)

[33] van Strien, A. J., van Duuren, L., Foppen, R. P. B. \& Soldaat, L. L. (2009): A typology of indicators of biodiversity change as a tool to make better indicators. - Ecological Indicators 9: 1041-1048.

[34] Verhulst, J., Báldi, A. \& Kleijn, D. (2004): Relationship between land-use intensity and species richness and abundance of birds in Hungary. - Agriculture, Ecosystems and Environment 104, 465-473.

[35] Vickery, J. A., Tallowin, J. R., Feber, R. E., Asteraki, E. J., Atkinson, P. W., Fuller, R. J. \& Brown, V. K. (2001): The managment of lowland neutral grasslands in Britain: effects of agricultural practices on birds and their food. The Journal of Applied Ecology 38: 647-664.

\section{Other resources}

[36] http://www.rspb.org.uk/ourwork/farming/whyfarming/whyfarming/fbi/ 